\title{
What is the food and nutrition security situation of Santa Catarina municipalities? Results of a multidimensional assessment
}

\section{Qual a situação de segurança alimentar e nutricional}

\section{dos municípios catarinenses? Resultados de}

uma avaliação de múltiplas dimensões

\author{
Amanda de Araújo Figueredo GUEDES ${ }^{1}$ (iD) 0000-0001-9494-9193 \\ Mick Lennon MACHADO2 ID 0000-0001-7550-1692 \\ Milena Corrêa MARTINS2 ID 0000-0001-5212-8661 \\ Barbara Leone SILVA² (ID) 0000-0001-8677-2981 \\ Patrícia Maria de Oliveira MACHADO 3 (ID) 0000-0002-8630-8318 \\ Cristine Garcia GABRIEL 2 (ID) 0000-0002-5413-0826
}

\section{A B S T R A C T}

\section{Objective}

To describe the food and nutrition security situation of all municipalities of a Brazilian state.

\section{Methods}

The investigation was conducted using an assessment matrix developed through consensus workshops. The matrix is composed of 7 dimensions, 11 subdimensions, 27 indicators, and 59 items. Data were collected at the municipal level from different public databases using the state of Santa Catarina as the case study basis.

1 Universidade Federal de Santa Catarina, Centro de Ciências da Saúde, Departamento de Nutrição. Florianópolis, SC, Brasil.

2 Universidade Federal de Santa Catarina, Centro de Ciências da Saúde, Programa de Pós-Graduação em Nutrição. Campus Universitário Reitor João David Ferreira Lima, Trindade, 88040-900, Florianópolis, SC, Brasil. Correspondence to: C.G. GABRIEL. E-mail: <cristine.gabriel@ufsc.br>.

${ }^{3}$ Universidade Federal da Integração Latino-Americana, Instituto Latino-Americano de Ciências da Vida e da Natureza, Curso de Medicina. Foz do Iguaçu, PR, Brasil.

How to cite this article

Guedes AAF, Machado ML, Martins MC, Silva BL, Machado PMO, Gabriel CG. What is the food and nutrition security situation of Santa Catarina municipalities? Results of a multidimensional assessment. Rev Nutr. 2020;33:e190267. https:// doi.org/10.1590/1678-9865202033e190267 
Municipalities were classified according to their food and nutrition security situation as poor, fair, good, or excellent.

\section{Results}

Of the 295 Santa Catarina municipalities, 65.4\% were rated as poor or fair in terms of food and nutrition security. The best-rated dimension was Continuing education, research, and training in food and nutrition security, followed by Agroecological production and sustainable food supply and Universal access to water and sanitation. The dimensions with the worst results were Food and nutrition at all levels of healthcare, Universal access to adequate food, and Assessment and monitoring. The dimension Traditional peoples and communities could not be evaluated because data were not available at the municipal level.

\section{Conclusion}

This study evidenced the need for a careful examination of the reality of Santa Catarina municipalities, as it made it possible to qualitatively characterize public policies within the context of food and nutrition security. The findings may contribute to the debate on evaluation and assist managers in strengthening food and nutrition security policies in Brazilian municipalities.

Keywords: Food and nutrition security. Program evaluation. Public policy.

\section{RE S U M O}

\section{Objetivo}

Apresentar a avaliação da situação de Segurança Alimentar e Nutricional do universo dos municípios de um estado brasileiro.

\section{Métodos}

A avaliação ocorreu por meio de uma matriz de análise e julgamento pactuada em oficinas de consenso, com 7 dimensões, 11 subdimensões, 27 indicadores e 59 medidas. Os dados foram coletados no nível municipal, em distintas bases públicas, utilizando como caso o estado de Santa Catarina. Os municípios foram classificados segundo sua situação de Segurança Alimentar e Nutricional em ruim, regular, bom ou ótimo.

\section{Resultados}

Dos 295 municípios, 65,4\% foram avaliados como ruins ou regulares. A dimensão melhor avaliada foi Processos Permanentes de Educação, Pesquisa e Formação em Segurança Alimentar e Nutricional, seguida por Sistemas de Produção Agroecológica e Abastecimento Sustentáveis de Alimentos e Acesso Universal à Água. As dimensões de Alimentação e Nutrição em Todos os Níveis de Atenção à Saúde, Acesso Universal à Alimentação Adequada e Avaliação e Monitoramento apresentaram os piores resultados. A dimensão de Povos e Comunidades Tradicionais não pode ser avaliada pela indisponibilidade de dados desagregados para o nível municipal.

\section{Conclusão}

A avaliação apontou a necessidade de olhar com cautela para a realidade dos municípios catarinenses, permitindo qualificar as políticas públicas no contexto da Segurança Alimentar e Nutricional. Almeja-se contribuir com o debate sobre a avaliação e auxiliar a gestão para o fortalecimento das políticas de Segurança Alimentar e Nutricional nos municípios brasileiros.

Palavras-chave: Segurança Alimentar e Nutricional. Avaliação de programas e projetos de saúde. Política pública.

\section{INTRODUCTION}

The concept of Food and Nutrition Security (FNS) encompasses the structure of the global food system and living conditions of the population, serving as a basis for pacts for development as a means to guarantee access to food and promote sustainable food production, distribution, and consumption $[1,2]$. The global relevance of FNS is evident: FNS public policies were identified in 123 countries, FNS reports in 139 countries, and both policies and monitoring reports in 114 countries [3]. 
The Brazilian government was a pioneer, and because of this gained international prominence, in the development of public policies to fight poverty, hunger, and food insecurity. Such policies permeate food and nutrition programs and help advance social protection and income transfer initiatives [4]. However, the national studies and tools available for assessing FNS focus on aspects such as nutrient intake and perception of food insecurity although more comprehensive and systemic evaluation proposals exist [5-8].

In line with the Food and Agriculture Organization of the United Nations (FAO) and the Brazilian Federative Pact, the Brazilian National Food and Nutrition Security Policy (NFNSP) is decentralized to federated entities. Despite setbacks in the federal coordination of the public policy in the past two years, state and municipal entities have fulfilled their commitments. Municipalities are responsible for legislative, administrative, and financial decisions regarding the planning and execution of NFNSP $[1,6]$. For this, it is crucial to assess and monitor FNS. Given that FNS is context-specific and is experienced in different ways at different locations, a territorial approach can potentially increase the efficiency of FNS policies, as it allows decision-makers to better manage actions and investments, ensure the overall coherence of the governance system, and capture the multidimensional and intersectoral nature of FNS [9].

Research aimed at evaluating and monitoring FNS from the wide perspective of the Brazilian FNS concept can contribute to the consolidation of the national FNS system $[7,8,10]$. Considering the above and the importance of local bodies for the implementation of NFNSP, this study assessed the FNS situation of all municipalities of a state in southern Brazil.

\section{METHODS}

This is an evaluative study with an exploratory-descriptive character and a quantitative approach. An FNS assessment matrix was constructed based on an evaluation model structured into seven dimensions, defined from theoretical and normative data, and discussed until agreement in consensus workshops with experts through the Delphi method. The model, developed to assess the relevance of state FNS plans, was tested and described in detail in a previous study [8]. Given that the model is built upon the premise of FNS proposed by the Brazilian legal framework, its dimensions were kept unchanged $[8,11]$. Alterations were only performed in subdimensions, indicators, and items to adapt the tool for municipal assessment. It is noteworthy that most subdimensions were maintained; however, five subdimensions from the original model had to be excluded because they did not apply to local scopes [8].

A search was conducted in Web of Science, PUBMED, SciELO, and Scopus for identification of FNS indicators. The search strategy, applied in English and Portuguese, was as follows: ((indicat ${ }^{\star}$ OR diagnos* OR instrument OR measur ${ }^{*}$ OR evalu*) AND (("Food and Nutrition Security" OR "Food and Nutrition Insecurity") OR ((Polic OR Program) AND ("Food and Nutrition Security" OR "Food and Nutrition Insecurity")))) and (((indica* OR diagnostic ${ }^{*}$ OR instrumento OR medi- OR avalia*) AND (("Segurança Alimentar e Nutricional" OR "Insegurança Alimentar e Nutricional") OR ((Política OR Programa) AND ("Segurança Alimentar e Nutricional" OR "Insegurança Alimentar e Nutricional"))))).

Methodological articles and studies on FNS assessment at individual, family, and territorial levels were included. There were no language or location restrictions. Exclusion criteria were duplicate articles, theoretical investigations, studies not published in full, and studies addressing specific 
policies and programs or evaluating specific FNS dimensions. A search of technical documents on FNS assessment was also performed on government websites.

The proposed indicators for assessing FSN at the municipal level were evaluated in workshops by experts in FSN and policy evaluation [8]. Disagreements and suggestions were discussed until consensus was reached on the need to modify indicators. At the end of the process, the 7-dimensional matrix was organized into 11 subdimensions and 27 indicators, as shown in Chart 1.

Fifty-nine items were then selected to compose measurable indicators using data collected from public secondary databases. At this step, we also defined the sources of information available from different institutions: Censo Sistema Único de Assistência Social (SUAS, Unified System of

Chart 1. Dimensions, subdimensions, and indicators used for assessment of food and nutrition security at the municipal level. Santa Catarina, Brazil, 2018.

\begin{tabular}{|c|c|c|}
\hline Dimension & Subdimension & Indicator \\
\hline \multirow[t]{9}{*}{ 1: Universal access to adequate food } & \multirow[t]{2}{*}{ Social vulnerability } & Number of socially vulnerable families ${ }^{\mathbf{a}, \mathbf{b}, \mathbf{c}, \mathbf{d}}$ \\
\hline & & Social inequality ${ }^{\mathrm{e}, \mathrm{f}}$ \\
\hline & \multirow[t]{3}{*}{ Income } & $\begin{array}{l}\text { Number of families served by income transfer } \\
\text { programs }^{\text {a }}\end{array}$ \\
\hline & & Access to income $e^{\mathbf{e}, \mathbf{g}}$ \\
\hline & & Access to work ${ }^{\mathrm{e}}$ \\
\hline & \multirow[t]{4}{*}{ Distribution of food and meals } & $\begin{array}{l}\text { Public programs for promotion of food and } \\
\text { nutrition security }^{\text {h }}\end{array}$ \\
\hline & & Local food establishments \\
\hline & & Government food purchase $e^{\mathbf{b}, \mathbf{j}, \mathbf{k}, \mathbf{l}}$ \\
\hline & & $\begin{array}{l}\text { Number of families living in poverty or extreme } \\
\text { poverty served by nonprofit food distribution } \\
\text { networks }^{\text {a }}\end{array}$ \\
\hline \multirow{4}{*}{$\begin{array}{l}\text { 2: Agroecological production } \\
\text { sustainable food supply }\end{array}$} & Access to land & Land reform ${ }^{m}$ \\
\hline & \multirow[t]{3}{*}{ Food production and supply } & Agricultural incentive programs $s^{\mathbf{k}, \mathbf{m}, \mathbf{n}}$ \\
\hline & & Access to social programs in rural communities ${ }^{m}$ \\
\hline & & Organic food production ${ }^{m}$ \\
\hline \multirow[t]{4}{*}{$\begin{array}{l}\text { 3: Continuing education, research, and } \\
\text { training in food and nutrition security }\end{array}$} & \multirow[t]{2}{*}{ Food and nutrition education } & $\begin{array}{l}\text { Food and nutrition education actions within the } \\
\text { scope of PNAE }\end{array}$ \\
\hline & & School Health Program actions ${ }^{\circ}$ \\
\hline & \multirow[t]{2}{*}{ Public education system } & Access to public education ${ }^{\mathbf{e}}$ \\
\hline & & Level of education ${ }^{\mathbf{e}}$ \\
\hline \multirow{5}{*}{$\begin{array}{l}\text { 4: Food and nutrition at all levels of } \\
\text { healthcare }\end{array}$} & \multirow{5}{*}{ Primary care } & Food and nutrition surveillance ${ }^{\mathfrak{p}}$ \\
\hline & & Promotion of adequate and healthy eating ${ }^{q}$ \\
\hline & & Prevention and control of health problems ${ }^{q}$ \\
\hline & & Sanitary and environmental surveillance $\mathbf{e}^{\mathbf{b}, \mathbf{q}}$ \\
\hline & & Access to primary care ${ }^{q}$ \\
\hline \multirow[t]{3}{*}{ 5: Universal access to water and sanitation } & \multirow[t]{3}{*}{ Water and sanitation } & Water supplye \\
\hline & & Sanitation ${ }^{\mathbf{e}}$ \\
\hline & & Waste collection ${ }^{\mathbf{e}}$ \\
\hline 6: Traditional peoples and communities & Traditional peoples and communities & $\begin{array}{l}\text { Access of traditional peoples and communities to } \\
\text { public services }^{r}\end{array}$ \\
\hline 7: Assessment and monitoring & $\begin{array}{l}\text { Assessment and monitoring of } \\
\text { SISAN }\end{array}$ & SISAN structure \\
\hline
\end{tabular}

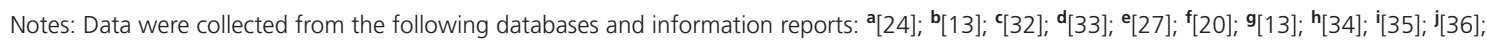
k[37]; '[38]; ${ }^{\mathrm{m}}[39] ;{ }^{\mathrm{n}}[40] ;{ }^{\circ}[41] ;{ }^{\mathbf{p}}[43] ;$ ' $[42] ;{ }^{\mathrm{r}}[26]$.

PNAE: Programa Nacional de Alimentação Escolar (National School Feeding Program); SISAN: Sistema Nacional de Segurança Alimentar e Nutricional (National Food and Nutrition Security System). 
Social Assistance); Municipal Human Development Index; E-Gestor Atenção Básica (AB, Primary Care); reports published by Ministério da Agricultura, Pecuária e Abastecimento (MAPA, Brazilian Ministry of Agriculture, Livestock, and Supply); MapaSAN (Mapeamento de SAN, FNS Mapping); PAA DATA, a database from Programa de Aquisição de Alimentos (Food Purchase Program); open data from Programa Nacional de Alimentação Escolar (PNAE, National School Feeding Program); Instituto Nacional de Estudos e Pesquisas Educacionais Anísio Teixeira (INEP, National Institute for Educational Studies and Research); Painel Programa Saúde na Escola (PSE, School Health Program); and DATASUS, a database provided by Sistema Único de Saúde (Unified Health System).

The assessment matrix was used to evaluate the FNS situation of all municipalities in Santa Catarina. Municipalities were selected for convenience, as the research integrates projects to strengthen the Sistema Nacional de Segurança Alimentar e Nutricional (SISAN, National Food and Nutrition Security System) in southern Brazil. Data collection took place between April and June 2018, using the most recent data available for each item. Scoring criteria were defined, and items were classified as poor, fair, good, or excellent.

For most items ( $n=48)$, a relative parameter was used, defined from the percentile distribution of municipalities. For instance, $25 \%$ of the municipalities with the worst results were classified as poor and, at the other extreme, $25 \%$ with the best results were classified as excellent. The others were classified as fair (25-50\%) or good (50-75\%). Absolute parameters were used for the remaining items $(n=11)$ on the basis of literature data or consensus among researchers. If a municipality lacked data for a specific item, it was classified as poor. Indicators for which data were not available at the municipal level but were considered relevant in the literature were kept in the assessment matrix; however, these indicators were not evaluated.

Scores were attributed to each classification and used to categorize indicators, subdimensions, dimensions, and overall FNS status of municipalities (Chart 2). Results are expressed as percentage distribution of municipalities across categories.

Chart 2. Scoring and rating criteria for Food and Nutrition Security (FNS) items, indicators, subdimensions, dimensions, and status. Santa Catarina, Brazil, 2018.

\begin{tabular}{|c|c|c|c|c|}
\hline Item & Indicator & Subdimension & Dimension & Municipal FNS status \\
\hline $\begin{array}{l}\text { If the item is rated as } \\
\text { poor, then the item } \\
\text { score is } 0 . \\
\text { If the item is rated } \\
\text { as fair, then the item } \\
\text { score is } 4 .\end{array}$ & $\begin{array}{l}\text { IS = mean score of all } \\
\text { items that compose the } \\
\text { indicator. } \\
\text { If } I S \geq 7.5 \text {, then the } \\
\text { indicator is rated as } \\
\text { excellent and the final } \\
I S=10 \text {. }\end{array}$ & $\begin{array}{l}\text { SS = mean final score of all } \\
\text { indicators that compose the } \\
\text { subdimension. } \\
\text { If SS } \geq 7.5 \text {, then the } \\
\text { subdimension is rated as } \\
\text { excellent and the final } S S=10 \text {. }\end{array}$ & $\begin{array}{l}\text { DS = mean final score of } \\
\text { all subdimensions that } \\
\text { compose the dimension. } \\
\text { If DS } \geq 7.5 \text {, then the } \\
\text { dimension is rated as } \\
\text { excellent and the final } \\
\text { DS }=10 \text {. }\end{array}$ & $\begin{array}{l}\text { FNS score }=\text { mean } \\
\text { final score of all FNS } \\
\text { dimensions. } \\
\text { If FNSS } \geq 7.5 \text {, then } \\
\text { the municipal FNS } \\
\text { status is rated as } \\
\text { excellent. }\end{array}$ \\
\hline $\begin{array}{l}\text { If the item is rated as } \\
\text { good, then the item } \\
\text { score is } 7 .\end{array}$ & $\begin{array}{l}\text { If } 7.5>\text { IS } \geq 5 \text {, then the } \\
\text { indicator is rated as } \\
\text { good and the final } I S=7 \text {. }\end{array}$ & $\begin{array}{l}\text { If } 7.5>S S \geq 5 \text {, then the } \\
\text { subdimension is rated as } \\
\text { good and the final } S S=7 \text {. }\end{array}$ & $\begin{array}{l}\text { If } 7.5>D S \geq 5 \text {, then the } \\
\text { dimension is rated as } \\
\text { good and the final } D S=7 \text {. }\end{array}$ & $\begin{array}{l}\text { If } 7.5>\text { FNSS } \geq 5 \text {, then } \\
\text { the municipal FNS } \\
\text { status is rated as } \\
\text { good. }\end{array}$ \\
\hline $\begin{array}{l}\text { If the item is rated as } \\
\text { excellent, then the } \\
\text { item score is } 10 .\end{array}$ & $\begin{array}{l}\text { If } 5>\text { IS } \geq 2.5 \text {, then the } \\
\text { indicator is rated as fair } \\
\text { and the final } I S=4 \text {. }\end{array}$ & $\begin{array}{l}\text { If } 5>S S \geq 2.5 \text {, then the } \\
\text { subdimension is rated as fair } \\
\text { and the final } S S=4 \text {. }\end{array}$ & $\begin{array}{l}\text { If } 5>D S \geq 2.5 \text {, then the } \\
\text { dimension is rated as fair } \\
\text { and the final } D S=4 \text {. }\end{array}$ & $\begin{array}{l}\text { If } 5>\text { FNSS } \geq 2.5 \text {, then } \\
\text { the municipal FNS } \\
\text { status is rated as fair. }\end{array}$ \\
\hline & $\begin{array}{l}\text { If IS }<2.5 \text {, then the } \\
\text { indicator is rated as poor } \\
\text { and the final } I S=0 \text {. }\end{array}$ & $\begin{array}{l}\text { If } \mathrm{SS}<2.5 \text {, then the } \\
\text { subdimension is rated as } \\
\text { poor and the final } S S=0 \text {. }\end{array}$ & $\begin{array}{l}\text { If } \mathrm{DS}<2.5 \text {, then the } \\
\text { dimension is rated as poor } \\
\text { and the final } D S=0 \text {. }\end{array}$ & $\begin{array}{l}\text { If FNSS }<2.5 \text {, then } \\
\text { the municipal FNS } \\
\text { status is rated as } \\
\text { poor. }\end{array}$ \\
\hline
\end{tabular}

Note: FNS: Food and Nutrition Security; FNSS: Food and Nutrition Security Score; IS: Indicator Score; SS: Subdimension Score. 


\section{R E S U L T S}

The FNS situation was rated excellent in 0 of the 295 municipalities analyzed, good in $34.6 \%$, fair in $64.7 \%$, and poor in $0.7 \%$ (Table 1). The best-rated dimension was Continuing education, research, and training in food and nutrition security, with $98.6 \%$ of municipalities classified as excellent. Agroecological production and sustainable food supply was rated good in $47.5 \%$ of municipalities and fair in 39.7\%. Municipalities were evenly distributed in their ratings on Universal access to water and sanitation. The dimensions Food and nutrition at all levels of healthcare, Universal access to adequate food, and Assessment and monitoring had the worst results, with 63.7, 83.0, and $92.2 \%$ of municipalities, respectively, classified as fair or poor. Traditional peoples and communities could not be assessed, as the available data were not stratified by municipality.

Table 1. Distribution of Santa Catarina municipalities according to food and nutrition security status, dimension, and subdimension ratings. Brazil, 2018

\begin{tabular}{|c|c|c|c|c|c|c|c|c|}
\hline \multirow{2}{*}{ Parameter } & \multicolumn{2}{|c|}{ Excellent } & \multicolumn{2}{|c|}{ Good } & \multicolumn{2}{|c|}{ Fair } & \multicolumn{2}{|c|}{ Poor } \\
\hline & $\mathrm{n}$ & $\%$ & $\mathrm{n}$ & $\%$ & $\mathrm{n}$ & $\%$ & $\mathrm{n}$ & $\%$ \\
\hline Food and nutrition security status & 0 & 0 & 102 & 34.6 & 191 & 64.7 & 2 & 0.7 \\
\hline Dimension 1: Universal access to adequate food & 0 & 0 & 50 & 16.9 & 224 & 75.9 & 21 & 7.1 \\
\hline Subdimension 1: Social vulnerability & 39 & 13.2 & 167 & 56.6 & 88 & 29.8 & 1 & 0.3 \\
\hline Subdimension 2: Income & 0 & 0 & 84 & 28.5 & 185 & 62.7 & 26 & 8.8 \\
\hline Subdimension 3: Distribution of food and meals & 2 & 0.7 & 50 & 16.9 & 57 & 19.3 & 186 & 63.1 \\
\hline $\begin{array}{l}\text { Dimension 2: Agroecological production and sustainable } \\
\text { food supply }\end{array}$ & 25 & 8.5 & 140 & 47.5 & 117 & 39.7 & 13 & 4.4 \\
\hline Subdimension 1: Access to land & 80 & 27.1 & 91 & 30.8 & 59 & 20.0 & 65 & 22.0 \\
\hline Subdimension 2: Food production and supply & 56 & 19.0 & 107 & 36.3 & 98 & 33.2 & 34 & 11.5 \\
\hline $\begin{array}{l}\text { Dimension 3: Continuing education, research, and training in } \\
\text { food and nutrition security }\end{array}$ & 164 & 44.6 & 130 & 44.1 & 1 & 0.3 & 0 & 0 \\
\hline Subdimension 1: Food and nutrition education & 291 & 98.6 & 4 & 1.4 & 0 & 0 & 0 & 0 \\
\hline Subdimension 2: Public education system & 73 & 24.7 & 94 & 31.9 & 52 & 17.6 & 76 & 25.8 \\
\hline Dimension 4: Food and nutrition at all levels of healthcare & 10 & 3.4 & 97 & 32.9 & 142 & 48.1 & 46 & 15.6 \\
\hline Subdimension 1: Primary care & 10 & 3.4 & 97 & 32.9 & 142 & 48.1 & 46 & 15.6 \\
\hline Dimension 5: Universal access to water and sanitation & 84 & 28.5 & 72 & 24.4 & 72 & 24.4 & 67 & 22.7 \\
\hline Subdimension 1: Water and sanitation & 84 & 25.5 & 72 & 24.4 & 72 & 24.4 & 67 & 22.7 \\
\hline Dimension 6: Traditional peoples and communities & * & * & * & * & * & * & * & \\
\hline Subdimension 1: Traditional peoples and communities & * & * & * & * & * & * & * & \\
\hline Dimension 7: Assessment and monitoring & 13 & 4.4 & 10 & 3.4 & 29 & 9.8 & 243 & 82.4 \\
\hline Subdimension 1: Assessment and monitoring of SISAN & 13 & 4.4 & 10 & 3.4 & 29 & 9.8 & 243 & 82.4 \\
\hline
\end{tabular}

Note: "data was not available.

SISAN, Sistema Nacional de Segurança Alimentar e Nutricional (National Food and Nutrition Security System).

Within the dimension Continuing education, research, and training in food and nutrition security, the subdimension Food and Nutrition Education (FNE) was rated excellent in $98.6 \%$ of municipalities. On the other hand, Public education system received a poor rating in $25.8 \%$ of municipalities.

The subdimension Food production and supply of the dimension Agroecological production and Sustainable food supply was classified as good in $36.3 \%$ of municipalities and fair in $33.3 \%$. Most municipalities (63.7\%) received fair or poor ratings in the dimension Food and nutrition at all levels of healthcare and only $3.4 \%$ received excellent ratings. 
Regarding the dimension Universal access to adequate food, the subdimension Income was rated fair or poor in $71.5 \%$ of municipalities and excellent in none. The subdimension Distribution of food and meals was rated poor in $63.1 \%$ of municipalities, and Social vulnerability was rated excellent or good in $69.8 \%$ of municipalities.

\section{DISCUSSION}

Food and Nutrition Security situation was assessed in all municipalities of a Brazilian state. The research was based on the legal frameworks of NFNSP, which highlight the importance of evaluating FNS status [11]. This study aligns with international literature underscoring the need for FNS issues to be addressed from a broad and systemic perspective and for the complexity of FNS to be contemplated at the local level [12].

The evaluated state, Santa Catarina, has 7,075,494 inhabitants and ranks third in Human Development Index in the country $[13,14]$. The state had the highest percentage of food secure households in Brazil (85.2\%) [15]. Santa Catarina takes part in SISAN, and the Conselho de Segurança Alimentar e Nutricional (CONSEA, Council of Food and Nutrition Security), Câmara Intersetorial de Segurança Alimentar e Nutricional (CAISAN, Intersectoral Chamber of Food and Nutrition Security), and the FNS Coordination are linked with the State Secretariat of Social Development [10]. The FNS plan of the state is considered one of the best structured in the country [10]. Nevertheless, the results of this study showed that it is crucial to carefully evaluate the reality of each municipality, as only $34.6 \%$ had a good FNS status and none were classified as excellent.

The dimension Continuing education, research, and training in Food and nutrition security, which had the best score, comprises indicators of FNE and School health program actions, Access to public education, and Education level of the population. Increasing the level of education is essential to minimize social differences and promote greater access to other rights, including food. Established as a PNAE guideline, FNE plays an important role in FNS [16]. However, the available data only allowed us to evaluate the presence or absence of FNE actions, not their quality.

Agroecological production and Sustainable food supply also received good scores. Its subdimensions are Access to land and Food production and supply. Santa Catarina stands out among other states in food production; it is one of the largest producers of poultry and pigs. About $90 \%$ of the rural population is engaged in family farming, a result of the land structure and natural heritage of the state. However, the development of family agriculture in Santa Catarina follows the national trend, with limited agroecological production [17].

The dimension Universal access to water and sanitation is associated with basic sanitation. Such conditions are sensitive to social vulnerability and determine the health situation of the population [18]. Santa Catarina ranked sixth in the supply of basic municipal sanitation services in 2008 [19]. Updated data on this issue is needed.

Chronic diseases accounted for $71 \%$ of deaths worldwide in 2016, and overweight was considered the main risk factor. According to the 2013 National Health Survey, Santa Catarina had the highest prevalence of obesity in Brazil, as reflected by municipal ratings in Food and nutrition at all levels of healthcare $[20,21]$. In this scenario of nutritional deficiency diseases and malnutrition, food and health nutrition actions need to be strengthened [22].

Universal access to adequate food is strongly related to social equality [23]. Municipalities are expected to provide families with the necessary work, income, and food conditions to prevent 
social vulnerability. As of 2014, poverty and extreme poverty have continuously increased in the country. In April 2020, about 48 million Brazilians were living in poverty or extreme poverty. In Santa Catarina, 470,263 individuals were living under these conditions, that is, approximately $7 \%$ of the state population [24].

The dimension Assessment and monitoring refers to the structural level of SISAN. The difficulty of municipalities in complying with this dimension is evidence of the limitations in the development and implementation of this policy at the municipal level. Decentralization of NFNSP is recent compared with the adherence of states to SISAN [25]. In joining the system, municipalities have the advantages of strengthening the design of public policies aimed at ensuring the right to adequate food and FNS and stimulating social participation through councils and conferences [1]. Lack of regular financing is one of the difficulties in implementing and executing FNS policies $[1,7]$. Policy managers play a crucial role in prioritizing the allocation of resources to FNS [10].

Prioritization of traditional peoples and communities in NFNSP is a strategy to overcome historical inequity, which has increased the vulnerability of these populations in relation to access to adequate food [26]. Santa Catarina had 16 certified quilombola communities in 2019 and an indigenous population of 16,041 individuals in 2010 [27,28]. Other important social groups in the state include traditional peoples and communities of African origin, artisanal fisher people, and gypsies. These groups should be the focus of state actions. However, the difficulty in locating municipal data on the FNS situation of these populations expresses the fragility of such prioritization. Overcoming this difficulty is one of the focuses of the II National FNS Plan. The goal is to identify and include these families in the Unified Registry for Social Programs. The Santa Catarina FNS Plan, in force until the end of 2019, aimed to map these social groups and communities in the state [9].

We highlight the importance of evaluative research carried out at the municipal level. With the advance of political-administrative decentralization in Brazil, municipalities have become the main implementers of public policies [29]. This reality is no different in the context of NFNSP [11]. Given that FNS depends on the political environment and necessitates the implementation of public policies that jointly promote economic growth, rural development, and social protection, local actions that consider the reality of each territory are essential [30].

The intersectoral character of FNS imposes numerous challenges to its implementation and requires multidimensional assessment models [7]. These tools are intended to provide policy managers with information and knowledge for informed decisions, thereby leading to the improvement of specific FNS issues [12].

Researchers and organizations around the world have developed tools, metrics, analytics, and scorecards, such as the Global Hunger Index, the Economist's Global Food Security Index, the World Health Organization's Landscape Analysis of Nutrition, and the Hunger and Nutrition Commitment Index, among others, to assess political commitment and promote accountability for the reduction of hunger and malnutrition [3]. However, the lack of federative agreements limits the shared development and implementation of FNS strategies and, consequently, qualitative analysis of FNS management and actions. Few studies have been carried out on this topic. A systematic review revealed the challenges and gaps in FNS governance and the absence of research on governmental arrangements at the subnational level [29].

It should also be noted that this study used secondary databases as sources of information, in accordance with NFNSP regulations, which recommend the use of information and indicators 
available in existing information systems of all sectors and spheres of the government for evaluation purposes [11]. Such databases are easily accessible and contribute to enhancing the speed of data collection [31]. Furthermore, by standardizing the data needed to measure FNS, researchers can compare results between municipalities.

\section{CONCLUSION}

This study developed an assessment model that considers all dimensions of the Brazilian concept of FNS and can be applied to secondary databases, allowing comparisons between municipalities and stimulating the use of public databases, aiming at their improvement. However, one limitation of such a strategy is the difficulty in finding municipal-level data.

As expected, policies and programs that are well consolidated and mandatory were better rated. Other policies require greater attention. This study provides important information to stimulate the debate about FNS assessment models and indicators, contributing to public management and social control of NFNSP. It is suggested that future studies use the assessment matrix to evaluate and characterize municipalities of other Brazilian states.

\section{CONTRIBUTORS}

AAF GUEDES, ML MACHADO, and CG GABRIEL participated in the study conception, design, and data analysis and interpretation. AAF GUEDES, BL SILVA, and ML MACHADO carried out the literature review All authors participated in the writing, revision, and final approval of the manuscript.

\section{REFERENCES}

1. Vasconcellos ABPA, Moura LBA. Segurança alimentar e nutricional: uma análise da situação da descentralização de sua política pública nacional. Cad Saúde Pública. 2018;34(2):e00206816. https://doi.org/10.1590/0102-3 $11 \times 00206816$

2. Castro IRR. The dissolution of the Brazilian National Food and Nutritional Security Council and the food and nutrition agenda. Cad Saúde Pública. 2019;35(2):e00009919. https://doi.org/10.1590/0102-311x00009919

3. Aliaga MA, Santos SMC. Food and nutrition security public initiatives from a human and socioeconomic development perspective: mapping experiences within the 1996 World Food Summ signatories. Soc Sci Med. 2014;104:74-9. https://doi.org/10.1016/j.socscimed.2013.12.025

4. Palmeira PA, Mattos RA, Salles-Costa R. Food security governance promoted by national government at the local level: a case study in Brazil. Food Security. 2020;12:591-606. https://doi.org/10.1007/s12571-019-0 1000-2

5. Azevedo E, Ribas MTGO. Estamos seguros? Reflexões sobre indicadores de avaliação da segurança alimentar e nutricional. Rev Nutr. 2016;29(2):241-51. https://doi.org/10.1590/1678-98652016000200008

6. Ribeiro J, Santos S, Soares T, Accioly J. Food and Nutritional Security: evaluation and determining factors in cities consortium, Bahia, Brazil. Demetra. 2018;13(1):83-100. https://doi.org/10.12957/demetra.2018.30001

7. Machado ML, Gabriel CG, Soar C, Mamed GR, Machado PMO, Lacerda JT et al. Adequação normativa dos planos estaduais de segurança alimentar e nutricional no Brasil. Cad Saúde Pública. 2018;34(1):e00206716. https://doi.org/10.1590/0102-311×00206716

8. Machado ML, Gabriel CG, Lacerda JT, Machado PMO. Strategic evaluation of the Food and Nutrition Security Plan of the State of Santa Catarina, Brazil. Rev Nutr. 2018;31(6):617-30. https://doi.org/10.1590/1678-9 8652018000600010 
9. Cistulli V, Rodríguez-Pose A, Escobar G, Marta S, Schejtman A. Addressing food security and nutrition by means of a territorial approach. Food Security. 2014;6(6):879-94. http://doi.org/10.1007/s12571-014-0 403-z

10. Machado ML, Gabriel CG, Soar C, Neves J, Oliveira JTC. State Plan for Food and Nutrition Security: potentialities and limitations. Rev Nutr. 2018;31(4):413-22. https://doi.org/10.1590/1678-98652018000400006

11. Presidência da República (Brasil). Decreto $n^{\circ} 7.272$, de 25 de agosto de 2010 . Regulamenta a Lei $n^{\circ} 11.346$, de 15 de setembro de 2006, que cria o Sistema Nacional de Segurança Alimentar e Nutricional - SISAN com vistas a assegurar o direito humano à alimentação adequada, institui a Política Nacional de Segurança Alimentar e Nutricional PNSAN, estabelece os parâmetros para a elaboração do Plano Nacional de Segurança Alimentar e Nutricional, e dá outras providências. Brasília: Diário Oficial da União; 2010 [citado 19 out 2020]. Disponível em: http://www.planalto.gov.br/ccivil_03/_ato2007-2010/2010/decreto/d7272.htm

12. Pérez-Escamilla R, Gubert MB, Rogers B, Hromi-Fiedler A. Food security measurement and governance: assessment of the usefulness of diverse food insecurity indicators for policy makers. Global Food Security. 2017;14:96-104. https://doi.org/10.1016/j.gfs.2017.06.003

13. Instituto Brasileiro de Geografia e Estatística. Cidades e Estados: Santa Catarina. Rio de Janeiro: Instituto; 2019 [citado 19 out 2020]. Disponível em: https://www.ibge.gov.br/cidades-e-estados/sc/.html?

14. Atlas do Desenvolvimento Humano no Brasil. Ranking: todos os estados. Brasília: Instituto de Pesquisa Econômica Aplicada; 2010 [citado 19 dez 2019]. Disponível em: https://atlasbrasil.org.br/ranking

15. Gubert MB, Santos SMC, Santos LMP, Pérez-Escamilla R. A municipal-level analysis of secular trends in severe food insecurity in Brazil between 2004 and 2013. Glob Food Secur. 2017;14:61-7. https://doi.org/10.1016/j. gfs.2017.03.004

16. Pedraza DF, Melo NLS, Silva FA, Araujo EMN. Avaliação do Programa Nacional de Alimentação Escolar: revisão da literatura. Ciênc Saúde Coletiva. 2018;23(5):1551-60. https://doi.org/10.1590/1413-812320 18235.17832016

17. Centro de Socioeconomia e Planejamento Agrícola (Santa Catarina). Dados e informações. Florianopolis: Centro; 2017 [citado 10 dez 2019]. Disponível em: https://cepa.epagri.sc.gov.br/

18. Neves-Silva P, Heller L. The right to water and sanitation as a tool for health promotion of vulnerable groups. Ciênc Saúde Coletiva. 2016;21(6):1861-70. https://doi.org/10.1590/1413-81232015216.03422016

19. Instituto Brasileiro de Geografia e Estatística. Pesquisa nacional de saneamento básico 2008. Rio de Janeiro: Instituto; 2008 [citado 17 dez 2019]. Disponível em: https://biblioteca.ibge.gov.br/visualizacao/livros/ liv45351.pdf

20. World Health Organization. Global Health Estimates 2015: deaths by cause, age, sex, by country and by region, 2000-2016. Genebra: Organization; 2018.

21. Instituto Brasileiro de Geografia e Estatística. Pesquisa Nacional de Saúde 2013. Rio de Janeiro: Instituto; 2013 [citado 17 dez 2019]. Disponível em: https://biblioteca.ibge.gov.br/visualizacao/livros/liv94522.pdf

22. Jaime PC, Delmuè DCC, Campelo T, Oliveira e Silva D, Santos LMP. Um olhar sobre a agenda de alimentação e nutrição nos trinta anos do Sistema Único de Saúde. Ciênc Saúde Coletiva. 2018;23(6):1829-36. https://doi. org/10.1590/1413-81232018236.05392018

23. Pautassi LC. La complejidad de articular derechos: alimentación y cuidado. Salud Colectiva. 2016;12(4):621-34. https://doi.org/10.18294/sc.2016.941

24. Secretaria de Avaliação e Gestão da Informação (Brasil). VIS Data 3 beta: pessoas em situação de pobreza e extrema pobreza inscritas no Cadastro Único. Brasília: Ministério da Saúde; 2020 [citado 28 jun 2020]. Disponível em: https://aplicacoes.mds.gov.br/sagi/vis/data3/data-explorer.php

25. Moura IF, Souza C, Canavesi F. Agroecologia nas políticas públicas e promoção da segurança alimentar e nutricional. Segur Aliment Nutr. 2016;23:1019-30. https://doi.org/10.20396/san.v23i0.8635617

26. Fundação Palmares (Brasil). Certificação quilombola. Brasília; Fundação; 2019 [citado 17 dez 2019]. Disponível em: http://www.palmares.gov.br/?page_id=37551. 2019

27. Instituto Brasileiro de Geografia e Estatística. Censo Demográfico 2010: famílias e domicílios. Rio de Janeiro: Instituto; 2012 [citado 17 dez 2019]. Disponível em: https://biblioteca.ibge.gov.br/visualizacao/periodicos/97/ cd_2010_familias_domicilios_amostra.pdf 
28. Souza C. Coordenação, uniformidade e autonomia na formulação de políticas públicas: experiências federativas no cenário internacional e nacional. Cad Saúde Pública. 2019;35(Suppl2):e00046818. https:// doi.org/10.1590/0102-311x00046818

29. Candel JJL. Food security governance: a systematic literature review. Food Secur. 2014;6(4):585-601. https:// doi.org/10.1007/s12571-014-0364-2

30. te Lintelo DJH, Munslow T, Pittore K, Lakshman R. Process tracing the policy impact of 'indicators'. Euro J Develop Res. 2020;(32):1312-37. https://doi.org/10.1057/s41287-019-00244-0

31. Pinheiro ALS, Andrade KTS, Silva DO, Zacharias FCM, Gomide MFS, Pinto IC. Gestão da saúde: o uso dos sistemas de informação e o compartilhamento de conhecimento para a tomada de decisão. Texto Contexto - Enferm. 2016;25(3):e3440015. https://doi.org/10.1590/0104-07072016003440015

32. Ministério do Desenvolvimento Social (Brasil). Censo SUAS. Brasília: Ministério; 2017 [citado 19 out 2020] Disponível em: https://aplicacoes.mds.gov.br/sagirmps/portal-censo/

33. Ministério da Saúde (Brasil). Cadastro Nacional de Estabelecimentos de Saúde. Brasília: Ministério; 2017 [citado 19 out 2020]. Disponível em: http://cnes. datasus.gov.br/

34. Câmara Interministerial de Segurança Alimentar e Nutricional (Brasil). Mapeamento de Segurança Alimentar e Nutricional. Brasília: Câmara; 2014. [citado 19 out 2020] Disponível em: https://dados.gov.br/dataset/ mapeamento-de-seguranca-alimentar-e-nutricional

35. Instituto Brasileiro de Geografia e Estatística. Estatísticas do Cadastro Central de Empresas. Rio de Janeiro: Instituto; 2018 [citado 10 out 2020]. Disponível em: https://www.ibge.gov.br/estatisticas/economicas/comercio/9 016-estatisticas-do-cadastro-central-de-empresas.html?=\&t=o-que-e

36. Ministério da Cidadania (Brasil). PAA Data. Brasília: Ministério; 2017 [citado 10 out 2020]. Disponível em: https://aplicacoes.mds.gov.br/sagi/paa/visi_paa_geral/pg_principal.php?url=abertura

37. Ministério da Educação. Dados abertos do programa de alimentação escolar. Brasília: Ministério; 2017 [citado 10 out 2020]. Disponível em: http://www.fnde.gov.br/dadosabertos/\#: :text=Plano\%20de\%20Dados\%20 Abertos\%20do\%20FNDE\&text=Programa\%20Nacional\%20de\%20Alimenta\%C3\%A7\%C3\%A30\%20 Escolar, dos\%20nutricionistas\%20cadastrados\%20no\%20programa

38. Instituto Nacional de Estudos e Pesquisas Educacionais Anísio Teixeira (Brasil). Censo Escolar. Brasília: Instituto; 2018 [citado 10 out 2020]. Disponível em: http://inep.gov.br/dados

39. Instituto Brasileiro de Geografia e Estatística. Censo Agropecuário. Rio de Janeiro: Instituto; 2010 [citado 10 out 2020]. Disponível em: https://www.ibge.gov.br/estatisticas/economicas/agricultura-e-pecuaria/21814-2 017-censo-agropecuario.html?=\&t=o-que-e

40. Ministério do Desenvolvimento Agrário (Brasil). Relatórios abertos. Brasília: Ministério; 2015.

41. Ministério da Saúde (Brasil). Painel Programa Saúde na Escola. Brasília: Ministério, 2018 [citado 10 out 2020]. Disponível em: https://aps.saude.gov.br/ape/pse

42. Ministério da Saúde (Brasil). Sistema de Vigilância Alimentar e Nutricional. Brasília: Ministério; 2018 [citado 10 out 2020]. Disponível em: http://sisaps.saude.gov.br/sisvan/

43. Ministério da Saúde (Brasil). DATASUS: Informações de saúde. Brasilíla: Ministério; 2018 [citado 10 out 2020]. Disponível em: http://www2.datasus.gov.br/DATASUS/index.php?area=0202

Receveid: January 10, 2020 Final version: July 2, 2020

Approved: September 15, 2020 